\section{The role of Muslim identity in predicting violent behavioural intentions to defend Muslims}

Group Processes \& Intergroup Relations 2020, Vol. 23(8) 1267-1282 (C) The Author(s) 2020

(c) (i)

Article reuse guidelines: sagepub.com/journals-permissions DOI: $10.1177 / 1368430220920929$ journals.sagepub.com/home/gpi

(S)AGE

\author{
Milan Obaidi, ${ }^{(1 D}$ Gulnaz Anjum, ${ }^{2 *}$ (D) Joanna Lindström, ${ }^{3 *}$ \\ Robin Bergh, ${ }^{4,5}$ Elif Celebi ${ }^{6}$ and Merve Baykal ${ }^{6}$
}

\begin{abstract}
A sense of shared Muslim suffering seems to play a key role in uniting Muslims around the world. Therefore, in the current paper we hypothesized that the social psychological underpinnings of Islamist extremism would be similar for Muslims living in the West and Muslims living in countries with prolonged and ongoing exposure to Western-led military interventions. Across 4 studies among Muslims in Pakistan and Afghanistan ( $\mathrm{Ns}_{\mathrm{s}}=425,402$, and 127) and Muslims living in 20 Western countries $(N=366)$, we examined a path model in which group-based anger mediated the link between Muslim identification, perceived injustice of Western military and foreign policy, and violent behaviour intentions. Our results indicate that regardless of whether Muslims live in places with prolonged and ongoing experience of Western military interventions or not, the social psychological factors predicting violent Islamist extremism appear to be similar. We discuss implications for future theory and research.
\end{abstract}

\title{
Keywords
}

extremist violent intentions, group-based emotion, group-based injustice, Islamist extremism, Muslim global identity

Paper received 15 October 2019; revised version accepted 31 March 2020.

"The blood pouring out of Palestine must be equally revenged ... the American people have chosen, consented to, and affirmed their support for the Israeli oppression of the Palestinians, the occupation and usurpation of their land, and its continuous killing, torture, punishment and expulsion of the Palestinians."

An excerpt from the videotape of Osama bin Laden following the 9/11 attacks (bin Laden, 2002).
${ }^{1}$ Center for research on extremism (C-REX), University of Oslo, Norway

${ }^{2}$ Institute of Business Administration, Pakistan

${ }^{3}$ Stockholm University, Sweden

${ }^{4}$ Uppsala University, Sweden

${ }^{5}$ Harvard University, USA

${ }^{6}$ Istanbul Sehir University, Turkey

*Shares second authorship.

Corresponding author:

Milan Obaidi, Department of Political Science, University of Oslo, Eilert Sundt Hus, Moltke Moes vei 31 Oslo, 0317, Norway.

Email: Milan.Obaidi@c-rex.uio.no 
"Your democratically elected governments continuously perpetrate atrocities against my people all over the world. And your support of them makes you directly responsible, just as I am directly responsible for protecting and avenging my Muslim brothers and sisters."

An excerpt from the videotape of Mohammad Sidique Khan following the London bombings in 2005 (Khan, 2005).

Osama bin Laden and Mohammad Sidique Khan, known terrorists responsible for two major terrorist attacks in the West, expressed very similar reasons for carrying out their respective attacks. Despite the fact that they grew up in different cultural contexts, they both mention the atrocities faced by their fellow Muslims elsewhere, and the need to avenge the plight of Muslims who have suffered at the hands of Western interventions. This suggests that, across different cultural contexts, the same underlying social psychological processes might explain why some individuals are compelled to commit violent extremist acts to defend Muslims.

Scholars from various disciplines have proposed various causes of Islamist extremism (see Loza, 2007), pointing to Islamic ideology (Silber \& Bhatt, 2007), political strategy (e.g., Furnish, 2005), social identification processes (Hogg, Meehan, \& Farquharson, 2010), threat perceptions (Obaidi, Kunst, Kteily, Thomsen, \& Sidanius, 2018; Obaidi, Thomsen, \& Bergh, 2018), and mental illness (Lankford, 2014; Piven, 2002). However, only a fraction of the academic literature on terrorism is based on empirical data (see Sageman, 2014; Silke, 2004). In a nascent line of social psychological research, some have applied a social identity perspective on collective action and group-based emotions to explain Islamist extremism (Doosje, Loseman, \& Van den Bos, 2013; Obaidi, Bergh, Sidanius, \& Thomsen, 2018; Tausch et al., 2011). According to these perspectives, Islamist extremism represents one example of general group identification processes. Even if such general explanations are plausible, there is still a need to examine these processes in different contexts where Islamist extremism is prevalent.
One could ask, for instance, whether the same identification processes that explain extremism among Muslim minorities in Western Europe can shed light on extremist violence in the Middle East. Such questions have not been examined in the literature to date.

Many scholars have argued that Islamist extremism is the result of Western-led military interventions and foreign policy in Muslimmajority countries (i.e., Pape, 2003; Sidanius, Kteily, Levin, Pratto, \& Obaidi, 2016). However, even in the absence of direct personal experience of Western-led occupation, perpetrators of Islamist extremist violence often allude to a sense of perceived injustice against Muslims globally (Khosrokhavar, 2005; Nesser, 2006). The feeling of injustice becomes particularly strong since many Muslims have come to see themselves as a unified community cutting across national borders, and that what matters is the experience of the group and not the experience of specific individuals (e.g., Obaidi, Bergh, Akrami, \& Anjum, 2019). It is therefore apparent that Muslim identity plays a key role in Islamist extremism, uniting Muslims through a perception of shared or collective suffering (Wagemakers, 2008) regardless of geographical location or personal experience. Importantly, this suggests that individual engagement in Islamist extremism might be explained by a similar model in the West and in Muslimmajority countries. The current paper aims to empirically test this notion.

Islamist extremism, broadly defined, encompasses behaviours, ideas, intentions, and attitudes that are in opposition to fundamental values and norms of society, including democracy and the rule of law (Schmid, 2013). We define Western military interventions as encompassing Western wars, sanctions, drone attacks, occupations, targeted killing operation campaigns, and crossborder raids.

\section{Theoretical Background}

Whilst few scholars have specifically outlined theoretical models that illustrate the social psychological antecedents of Islamist extremism per se, a review of social identity theory (SIT; Tajfel \& 
Turner, 1979) and subsequent theorizing and research on collective action and relative deprivation (e.g., Abrams \& Grant, 2012; Becker \& Tausch, 2015; Simon \& Klandermans, 2001; Smith, Pettigrew, Pippin, \& Bialosiewicz, 2012; Van Zomeren, Postmes, \& Spears, 2008) is consistent with the notion that group identification and negative group-based emotions (i.e., injustice, anger) underlie willingness to engage in collective action (Smith \& Ortiz, 2002; Walker \& Smith, 2002). According to SIT (Tajfel \& Turner, 1979), people think, feel, and act, in part due to the circumstances of the groups with which they identify. Members of disadvantaged groups who perceive this disadvantage as illegitimate and unjust are more inclined to identify with their group and engage in collective action in an attempt to rectify the perceived inequality (Ellemers, Wilke, \& Van Knippenberg, 1993; Klandermans, 2002). Thus, according to SIT, identification with a disadvantaged group is a predictor of collective action (Kelly \& Breinlinger, 1996; Mummendey, Kessler, Klink, \& Mielke, 1999).

Van Zomeren et al. (2008) have conducted a comprehensive meta-analysis on the effects of identity, perceived injustice, and efficacy on collective action. Of particular relevance to the present study, Van Zomeren et al. (2008) found that the association between disadvantaged group identification and intention to engage in collective action is partially mediated by subjectively experienced group-based injustice. Van Zomeren's meta-analysis also laid the foundation for the development of the social identity model of collective action (SIMCA), an integrative theoretical model of collective action which proposes that social identity predicts collective action directly, as well as indirectly via groupbased injustice and group-based efficacy.

Moreover, individuals who more strongly identify with their group are more inclined to think, feel, and act for their group when their group is disadvantaged (Van Stekelenburg, 2013; van Zomeren et al., 2008). Group identification predicts collective action directly (e.g., De Weerd \& Klandermans, 1999; Stürmer \& Simon, 2004; Wright, Taylor, \& Moghaddam, 1990), but it also predicts other motivations for collective action, such as group-based anger and feelings of injustice (e.g., Grant, 2008; Mackie, Devos, \& Smith, 2000; Van Zomeren, Spears, Fischer, \& Leach, 2004). Furthermore, such processes are more likely when differences between groups become increasingly salient (Turner, 1999; Turner et al., 1987). In other words, the more people talk about differences between Muslims and Westerners, and the more these groups appear to behave differently, we would expect stronger cognitive, emotional, and behavioural reactions associated with such group identities. Recently, the Social Identity, Relative Deprivation, collective Efficacy (SIRDE) model of social change has combined the social identity, relative deprivation, and collective efficacy perspectives to predict participation in protest action (Abrams \& Grant, 2012). According to the SIRDE model, strong group identification in combination with feelings of deprivation, anger, and lack of collective efficacy is a stronger predictor of collective protests (Grant, Bennett, \& Abrams, 2017).

In sum, the reviewed models are applicable to any social identity when ingroup identification is seen to be important to people. Nevertheless, this line of research has mostly been studied in the context of Western countries mainly focusing on protest actions (i.e., student protest, voting behaviour). However, recent work has successfully applied insights from research on relative deprivation, social identity, and intergroup emotion to explain normative and nonnormative collective action among Muslim minority groups (i.e., Doosje et al., 2013; Obaidi et al., 2019; Tausch et al., 2011).

In the past two decades, Muslim identity has become increasingly salient, particularly when scholars as well as prominent politicians such as Donald Trump emphasize a "clash of civilizations" between Muslims and non-Muslims (Haynes, 2017; Huntington, 1993). In part due to this "clash of civilizations" rhetoric, Muslims are subject to discrimination globally (Adida, Laitin, \& Valfort, 2016; Bansak, Hainmueller, \& Hangartner, 2016), with anti-Muslim activities and violence against Muslims intensifying in the last 
decade (McKenzie, 2018; Tajuddin, 2018), leading to feelings of anger and deprivation. Consequently, in the midst of growing tensions between Muslims and non-Muslims, Muslim identification is central to Muslims' sense of self (Branscombe, Schmitt, \& Harvey, 1999; Roy, 2004).

In line with this reasoning, Obaidi, Bergh, et al. (2018) examined both violent as well as nonviolent intentions among Muslims living in Denmark. Specifically, based on insights from social categorization and intergroup emotions theory as well as collective action literature, Obaidi, Bergh, et al. (2018) proposed and tested a model with Muslim identification and perceived injustice of Western foreign policy and interventions (against Muslim countries) as independent variables, violent and nonviolent behavioural intentions as dependent variables, and group-based anger as a mediator. Consistent with this model, Muslim identification, group-based anger, and perceived injustice were all positively associated with violent intentions to defend Islam and other Muslims. However, Obaidi, Bergh, et al. (2018) focused mainly on vicarious processes and past experiences of Muslims living in the West (whether reactions would differ for Muslims who were born in the West or not). Hence, they did not address to what extent there are effects of prolonged and current exposure to Western country interventions in Muslim-majority countries.

Some research suggests that different exposure to violence affects both prosocial and antisocial behaviours at a local level (i.e., affecting interpersonal relations or leading to different behaviours towards other villages compared to one's own; Bauer, Cassar, Chytilová, \& Henrich, 2014; Swedo et al., 2019). In contrast, we examined global effects of experiences and threat of missile strikes, power outages, disrupted transportations, etc., as a result of a foreign (Western) power's military actions among Muslims in Afghanistan and Pakistan, compared to not experiencing such conditions (the case for Muslims in Europe).

Here, we explored the possibility that individual engagement in Islamist extremism might have a common identity-based explanatory model in the West and in Muslim-majority countries. Muslims may come to identify with a global Muslim community (ummah) due to perceptions of different threats that target Muslims (i.e., discrimination in the West, or military threats in the Middle East). Hence, identification with a global Muslim community can be seen as a coping strategy to mitigate the impacts of such experiences. According to SIT, ethnic or racial discrimination may lead individuals to seek a sense of belonging to and acceptance in their in-group communities (Tajfel \& Turner, 2004). Indeed, previous research shows that some people strongly identify with their ingroup in the face of threat and discrimination (Branscombe et al., 1999), and that strong ingroup identification, in turn, mitigates the aversive effect of difficult psychological states (Pargament, Smith, Koenig, \& Perez, 1998; Ruffle \& Sosis, 2007). Further, recent studies show that the experience of intergroup conflict and war-related violence fosters more group participation (Voors et al., 2012) and increases people's engagement with their religious group (Henrich, Bauer, Cassar, Chytilová, \& Purzycki, 2019), which may help people cope with aversive psychological effects (Pargament et al., 1998). However, when group identification is politicized and coupled with aversive experiences, such as discrimination and injustice, it may lead to collective action on behalf of one's group (e.g., Stürmer \& Simon, 2004). In particular, a Muslim identity based on collective suffering could explain why individuals who have committed extremist violence often express anger and feelings of injustice over Western-led military interventions faced by their fellow Muslimsregardless if they live in countries targeted by such interventions or not.

Nevertheless, there is still a need to directly examine whether the social psychological underpinnings of political violence are similar among Muslims living in Muslim-majority countries and Muslims living in the West. Similarity across these contexts would imply that group identification processes and the associations between the psychological variables do indeed cut across borders, contexts, and varying degrees of personal experience of war 
and occupation, hence supporting the underlying role of a Muslim identity in predicting Islamist extremism (this is not to say that Muslim identification always leads to extremism, however; see the General Discussion section).

\section{The Present Research}

The aim of this paper was to examine if predictors of Islamist extremism in the West reappear and are similarly interrelated in Muslim-majority countries with prolonged and ongoing experience of Western-led military interventions. We hypothesized that the individual difference variables that predict violent behavioural intentions would be the same across countries, regardless if the country was the target of military actions by Western powers or not. To the best of our knowledge, no studies to date have directly assessed the cross-cultural generalizability of a social psychological model of Islamist extremism by directly and empirically comparing models of extremism in Western countries and in Muslim-majority countries that are subject to Western military interventions. Thus, we sampled Muslims from two such Muslim-majority countries-Pakistan and Afghanistan-where extremism is also prevalent (Samples 1a and 1b were collected in Pakistan, and Study 2 in Afghanistan). We also collected data from Pakistani Muslims living in 20 different Western countries (Sample 1c), for comparison with our participants living in Muslim countries. We tested our hypotheses in a path analytic framework where we compared these four samples. Across all samples, we examined whether Muslim group identification and injustice appraisals of Western foreign policy would predict intentions to commit violence on behalf of Muslims, through group-based anger.

\section{Rationale for Focusing on Pakistan and Afghanistan}

In the following, we first describe the reasons why we focus on Pakistan and Afghanistan, and then we describe each sample. In the first three samples, we focused on Muslims of Pakistani origin living in Pakistan (Samples 1a and 1b), as well as sampling Pakistani Muslims living in 20 different Western countries (Sample 1c). Pakistan is currently among the countries with the greatest prevalence of terrorist attacks (National Consortium for the Study of Terrorism and Responses to Terrorism [START], 2018), which appear to occur in response to Western interventions (Cronin, 2013; Hussain, 2015). Importantly, terrorism in Pakistan has been known to spread not only to neighboring countries, such as India and Afghanistan, but globally as well, with a number of terrorist attacks occurring in the West having ties to extremist groups in Pakistan (Andre \& Harris-Hogan, 2013). Furthermore, in a global armed conflict against Al-Qa'ida, the Pakistani Taliban, and in the context of the post- $9 / 11$ war on terror, Pakistan has been increasingly the target of airstrikes, occasional Special Forces attacks, cross-border raids, targeted killings, and drone strikes by the US resulting in numerous civilian casualties (Anjum, Aziz, Castano, 2019; Anjum, Castano, \& Aziz, 2016). The numerous civilian casualties create anger and anti-Western resentment, providing a breeding ground for terrorist recruitment and incitement of Islamist extremism (Cronin, 2013; Hussain, 2015). Thus, if Islamist extremism results from experiences of living in a country consistently targeted by Western military actions, then Pakistan would be an ideal country to study these effects. For comparison, we explored whether the same model might also apply to Pakistanis who have moved to Western countries (who could be assumed to be more positive toward the West, given daily contact with non-Muslim Westerners).

For Study 2, we turned to Afghanistan, a country being targeted by extensive interventions from Western powers. Afghanistan was invaded by the US and their allies following the terrorist attacks of $9 / 11$. As of January 2015, the Watson Institute of Brown University estimated that more than 26,000 civilian Afghans have been killed, and nearly 100,000 people have been injured and maimed since the 2001 occupation of the country. In total, the U.S.-led war has resulted in 92,000 casualties in all categories of direct war 
violence (Watson Institute for International and Public Affairs - Brown University, 2015). Further, the war and occupation has exacerbated the effects of poverty, malnutrition, poor sanitation, and lack of access to health care (Watson Institute for International and Public Affairs - Brown University, 2015). Moreover, the country is a major target of U.S. airstrikes, resulting in a large number of civilian casualties. For instance, documents show that during the course of a 5-month targeted killing operation campaign, nearly 9 out of 10 people who died in airstrikes were not the U.S. military's direct targets (Devereaux, 2015). Furthermore, in part due to the ongoing U.S. war against terrorism, terrorist attacks are common in Afghanistan, with the country ranking second (after Iraq) as the country with the most terrorist attacks in 2017 (National Consortium for the Study of Terrorism and Responses to Terrorism [START], 2018).

\section{Study 1}

\section{Sample $1 a$}

Participants and procedure. Study $1 \mathrm{a}$ and the subsequent studies were approved by the Institutional Review Board of the primary affiliation of the first and second authors. Participants were asked to take part in a study investigating social and political issues faced by their respective societies. The first page of the survey was an informed consent form; participants needed to give their consent in order to proceed. Although we had planned to exclude any non-Muslim participants, all participants identified as Muslims. Since we had no other exclusion criterion, no participants were excluded from our study.

In this sample, a total of 425 Pakistani participants $\left(M_{\text {age }}=23.82, S D_{\text {age }}=5.35 ; 60.5 \%\right.$ female $)$ living in Pakistan were recruited from universities in Islamabad. The study was conducted in 2017 and it was a paper-and-pencil study. Data collection took roughly three months to complete. Both private and public sector universities were selected in an effort to obtain a diverse pool of participants, particularly with regard to socioeconomic background. Moreover, students were selected from these universities because they get a fairly equal representation from various socioeconomic and provincial backgrounds. All students volunteered to participate in the study. Of the total sample, $5.4 \%$ of participants indicated that they were upper class, $72.2 \%$ upper middle class, $18.3 \%$ lower middle class, and $4.0 \%$ working class. ${ }^{1}$ All participants were born in Pakistan.

\section{Sample 1b}

Participants and procedure. Study 1a was conducted in 2018 among students from both private and public sector universities. Data collection took roughly three months to complete. The Higher Education Commission of Pakistan have raised concerns about the recent observation that Pakistani students from private universities hold more moderate attitudes toward extremism compared to students from public universities (Higher Education Commission Pakistan, 2017). Therefore, in Study $1 \mathrm{~b}$ we only targeted students from public universities $^{2}$ in Karachi. A total of 402 participants $\left(M_{\text {age }}=21.06, S D_{\text {age }}=1.89 ; 40.3 \%\right.$ female $)$ were approached directly by four research assistants in two major public universities. All participants were born in Pakistan and identified as Muslims. A combination of convenience and snowball sampling was used to recruit the participants. Of the total sample, $13.2 \%$ of participants indicated that they were upper class, $77.1 \%$ upper middle class, $8.2 \%$ middle class, and $1.0 \%$ lower middle class. ${ }^{3}$

\section{Sample 1c}

Participants and procedure. Data for Sample 1c were collected in 2017 among Pakistani Muslims living in 20 different Western countries $\left(M_{\text {age }}=24.48\right.$, $S D_{\text {age }}=4.82 ; 50.5 \%$ female). Data collection took roughly three months to complete. The sample comprised 366 Muslims living in the United Kingdom (22.7\%), the United States $(19.7 \%)$, Canada (10.7\%), Germany $(7.7 \%)$, Norway $(4.1 \%)$, France $(3.8 \%)$, Australia (3.6\%), Sweden (3.6\%), and Switzerland (3.3\%). For more details, see Table S3 in the online supplemental material. A combination of convenience 
and snowball sampling was used to recruit the participants. Specifically, participants were recruited by four university students and three research assistants both directly and via various Facebook pages and other portals for Pakistani immigrants living abroad. All participants identified as Muslims. Of the total sample, $18 \%$ of participants indicated that they were upper middle class, $67.6 \%$ middle class, $12.6 \%$ lower middle class, and $1.9 \%$ working class. ${ }^{4}$

\section{Study 2}

\section{Participants and Procedure}

Study 2 was conducted in 2018 among Afghans in Kabul. It was an online study using a convenience sample from Facebook. We recruited 127 Afghans $\left(M_{\text {age }}=27.9, S D_{\text {age }}=7.72 ; 46 \%\right.$ female $)$, and data collection took approximately three months. All of our participants were born in Afghanistan and identified as Muslims. Of the total sample, $15.7 \%$ of participants indicated that they were upper class, $25.2 \%$ upper middle class, $29.9 \%$ middle class, $18.9 \%$ lower middle class, and $7.1 \%$ working class. ${ }^{5}$

\section{Method}

Power rationale. We used a multigroup analysis to examine whether the path model is similar across all samples. A question then was how much the samples might vary before rejecting the notion of a common model. Thus, we estimated the power for detecting overall differences in the model raising the RMSEA to .05, a conventional cut-off for "close fit" (see MacCallum, Browne, \& Cai, 2006; see also Preacher \& Coffman, 2006, for implementation). In addition, we ran a simulation to examine the power for detecting sample differences in particular coefficients. Here we used results from Obaidi, Bergh, et al. (2018) as population values, except that we set one path to zero in the smallest sample (compared to 0.22 in the other three samples). The power to detect such a difference was .93. Assuming a smaller difference, 0.07 versus 0.22 , the power would be .68 (see page 7 of supplemental material for more details).
Measures. All items were answered on 7-point Likert scales $(1=$ strongly disagree, $7=$ strongly agree). In Afghanistan, the survey was administered in Dari. All items were translated into Dari and subsequently back-translated into English. Among Pakistanis living in Pakistan and in the West, the surveys were either conducted in Urdu or English. For the Urdu survey, all items were translated into Urdu and subsequently backtranslated into English.

Muslim identification. Four items were used to measure participants' Muslim identification (e.g., "I strongly identify with other Muslims"; $\alpha$ s > .86; see Doosje, Ellemers, \& Spears, 1995; Obaidi et al., 2019; Obaidi, Bergh, et al., 2018) with the exception of Study 2, in which Item 4 was reverse-coded ( $\alpha$ s $=.94)$.

Perceived injustice. Five items from Obaidi and colleagues (Obaidi et al., 2019; Obaidi, Bergh, et al., 2018; see also Tausch et al., 2011) were used to measure participants' perceived injustice (e.g., "Muslims in Muslim countries suffer because of the foreign policy of Western countries"; $\alpha s>.83)$.

Group-based anger. Three items from Obaidi and colleagues (Obaidi et al., 2019; Obaidi, Bergh, et al., 2018; see also Tausch et al., 2011) were used to measure participants' groupbased anger (e.g., "I feel angry when I think of Western countries' foreign policies towards Muslim countries"; $\alpha_{s}>.91$ ), with the exception of Study 2, in which Item 3 was reverse$\operatorname{coded}\left(\alpha_{\mathrm{s}}=.81\right)$.

Violent behavioural intentions. Violent behavioural intentions were assessed using two items (e.g., "I am ready to use violence against other people in order to achieve something I consider very important" and "I am ready to use violence against other people in order to change Western countries' foreign policy towards Muslim countries"6; $\alpha$ s $>.51$; see Obaidi et al., 2019; Obaidi, Bergh, et al., 2018; see also Doosje et al., 2013). 
Table 1. Descriptive statistics and variable intercorrelations for Studies 1 (Samples 1a, 1b, and 1c) and 2.

\begin{tabular}{|c|c|c|c|c|c|c|}
\hline & Variables & $M$ & $S D$ & 2. & 3. & 4. \\
\hline \multirow{5}{*}{$\begin{array}{l}\text { Muslim } \\
\text { majority: } \\
\text { Pakistan }\end{array}$} & Sample 1a & & & & & \\
\hline & 1. Muslim identification & 5.22 & 1.38 & $.37 * *$ & $.38^{* *}$ & $.30^{* *}$ \\
\hline & 2. Perceived injustice & 4.47 & 1.21 & & $.68^{* *}$ & $.35^{* *}$ \\
\hline & 3. Group-based anger & 4.17 & 1.52 & & & $.48^{* *}$ \\
\hline & 4. Violent intentions & 2.84 & 1.37 & & & - \\
\hline \multirow{5}{*}{$\begin{array}{l}\text { Muslim } \\
\text { majority: } \\
\text { Pakistan }\end{array}$} & Sample $1 \mathrm{~b}$ & & & & & \\
\hline & 1. Muslim identification & 5.26 & 1.22 & $.39 * *$ & $.37 * *$ & $.22 * *$ \\
\hline & 2. Perceived injustice & 4.56 & 1.41 & - & $.75^{* *}$ & $.57^{* *}$ \\
\hline & 3. Group-based anger & 4.29 & 1.79 & & - & $.53 * *$ \\
\hline & 4. Violent intentions & 4.98 & 1.78 & & & - \\
\hline \multirow{5}{*}{$\begin{array}{l}\text { Muslim } \\
\text { minority: } \\
\text { The West }\end{array}$} & Sample 1c & & & & & \\
\hline & 1. Muslim identification & 5.04 & 1.39 & $.51^{* *}$ & $.51 * *$ & $.39 * *$ \\
\hline & 2. Perceived injustice & 4.70 & 1.19 & - & $.74 * *$ & $.53 * *$ \\
\hline & 3. Group-based anger & 4.41 & 1.52 & & - & $.54 * *$ \\
\hline & 4. Violent intentions & 3.16 & 1.51 & & & - \\
\hline \multirow{5}{*}{$\begin{array}{l}\text { Muslim } \\
\text { majority: } \\
\text { Afghanistan }\end{array}$} & Study 2 & & & & & \\
\hline & 1. Muslim identification & 4.82 & 1.29 & $.21 *$ & $.30^{* *}$ & .06 \\
\hline & 2. Perceived injustice & 4.29 & 1.78 & - & $.71 * *$ & $.49 * *$ \\
\hline & 3. Group-based anger & 4.22 & 1.84 & & - & $.60^{* *}$ \\
\hline & 4. Violent intentions & 3.76 & 1.94 & & & - \\
\hline
\end{tabular}

Note. ${ }^{*} p<.05 . * * p<.01$.

\section{Results}

Variable descriptive statistics and correlations for Samples 1a, 1b, 1c, and Study 2 can be found in Table 1.

\section{Multigroup Path Analyses (Samples 1a, 1b, 1c, and Study 2)}

To address the objectives of this paper, we conducted a multigroup path analysis, comparing two samples of Muslim Pakistanis living in Pakistan, Muslim Afghans living in Afghanistan, and Muslim Pakistanis living in Western societies. Multigroup structural equation modelling (and multigroup path and factor analyses) is a standard method to examine if the relation between a set of variables is similar across different samples (Jöreskog, 1971). Differences across samples were evaluated by constraining parameters (e.g., regression coefficients) as equal across samples, which could be compared to a (saturated and perfectly fitting) model without such constraints.
In our theoretical model, Muslim identification and perceived injustice were independent variables, violent intentions the dependent variable, and group-based anger was positioned as a mediator. Across all the samples, the models were estimated using robust maximum likelihood (MLR) in Mplus Version 7 (Muthén \& Muthén, 2012) in order to account for skewed variables. Full information maximum likelihood (FIML) is used by default in Mplus to handle missing data (missing $<3 \%$ for any variable in these data).

We first estimated a model where all paths were constrained to equality across the groups (Muslim Pakistanis living in Pakistan, Muslims living in Afghanistan, and Muslims living in Western countries). In other words, the model tests the assumption that the relations between the variables are the same in Pakistan, Afghanistan, and Western societies, net of random variability. The constrained model fit the empirical data reasonably well; scaled $\chi^{2}(18)=47.12, p<.001$, $\mathrm{CFI}=.97$, RMSEA $=.07,90 \%$ CI $[0.05,0.09]$, $\mathrm{SRMR}=.08$. 
Figure 1. Standardized results of a multigroup path analysis (Samples 1a, 1b, 1c, and Study 2) to predict violent intention to defend Muslims.

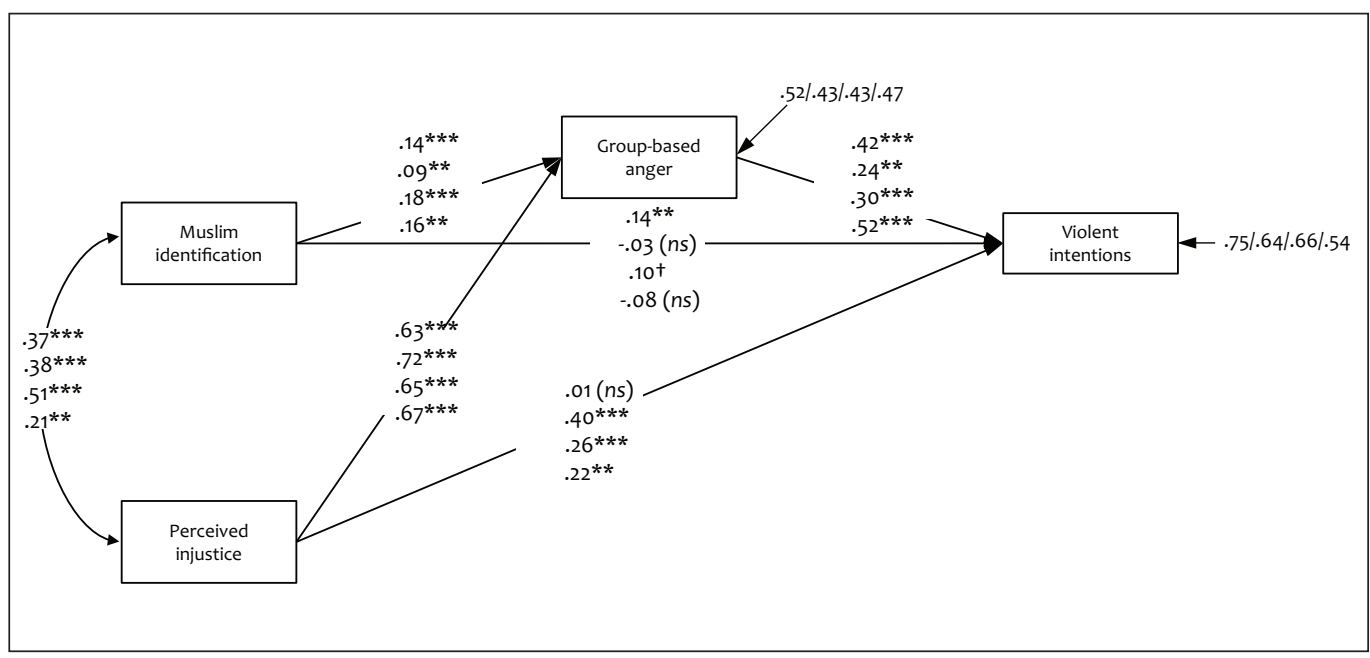

We also inspected modification indices for individual paths that might differ across the four samples. The fit improved further when we released the constraint for one path in the first sample from Pakistan (see Sample 1a, Participants and Procedure section) - from perceived injustice to violent intentions, $\chi^{2}(17)=30.76, p=$ $.02, \mathrm{CFI}=.99, \mathrm{RMSEA}=.05,90 \%$ CI $[0.02$, $0.08]$, SRMR $=.07$. Additional modifications were associated with small changes in model fit (second potential improvement: $\triangle$ RMSEA $=$ $.006, \Delta \mathrm{CFI}=.003)$, compared to guidelines considering $\triangle \mathrm{RMSEA}>.015$ and $\Delta \mathrm{CFI}>.01 \mathrm{sub}-$ stantial enough to disconfirm assumptions of invariance across groups (Chen, 2007; Cheung \& Rensvold, 2002).

Overall, this indicates that the relationships between the variables were similar across all four samples, with one exception being the first sample obtained in Pakistan (Sample 1a). To illustrate the minor variations in the path coefficients overall, we present (all freely estimated) standardized coefficients in each sample in Figure 1.

We further examined the indirect effects using bootstrapping with 5,000 random resamples in the model with all coefficients being held equal across samples (i.e., we tested one common mediation model). This analysis was based on regular maximum likelihood estimation. Both Muslim identification $(B=0.06,95 \%$ CI $[0.04,0.08])$ and perceived injustice $(B=0.28,95 \%$ CI $[0.22$, $0.34])$ had an indirect positive effect on violent intentions via group-based anger.

To test whether these findings were robust to the introduction of demographic variables, we ran the same model controlling for the effects of age, gender, and socioeconomic status. All paths that were significant without these control variables remained as strong in this analysis $(\beta \mathrm{s}$ $\geqslant .09$, ps $\leqslant .01)$.

Overall, the results of Samples 1a, 1b, and Study 2 among Muslims living in Muslim-majority countries (i.e., Pakistan and Afghanistan), and Sample 1c among Muslims living in 20 different Western countries indicate that the social psychological predictors of Islamic extremism in the West are similarly interrelated in Muslim-majority countries that have been the direct and prolonged target of Western military interventions.

\section{General Discussion}

Across four studies, we assessed the generalizability of a social psychological model of Islamist extremism. We directly and empirically compared the results obtained from Muslim-majority countries with prolonged and ongoing exposure 
to Western military and foreign policy (i.e., Pakistan and Afghanistan) to results obtained from Muslims in the West (sampled from 20 different Western countries). In particular, we examined whether Muslim group identification and injustice appraisals of Western military and foreign interventions would predict intentions to commit violence on behalf of Muslims, through group-based anger. Results of the multigroup path analyses provide evidence that the social psychological predictors of Islamist extremism generalized across the different contexts, with one minor exception for sample $1 \mathrm{a}$. To our knowledge, the present research is among the first to empirically examine social identity predictors of violent intentions among Muslims living in Muslim-majority countries. Importantly, the present research is also among the first to specifically examine the generalizability of a social psychological model of Islamist extremism by directly examining whether the relationships between the variables are consistent across Muslim-majority and Muslim-minority samples with differing exposure to Western-led wars and occupation.

Despite the differences in exposure to Western-led foreign policies and military interventions, and different political landscapes and cultural contexts, we obtained similar results across all our studies. Results from both Muslimmajority countries (with direct and prolonged exposure to Western military interventions) and Western Muslims (without such ongoing exposure) were consistent with a previous study conducted in the West (Obaidi, Bergh, et al., 2018). This provides further empirical evidence for the role of a Muslim identity as an underlying factor in radicalization, and the converging validity of our results.

Identification with a disadvantaged group is a key predictor of collective action (Van Zomeren et al., 2008). In the context of the present studies, identifying with a disadvantaged group (i.e., Muslims) did not directly predict nonnormative collective action (i.e., violent behavioural intentions) across all four studies, but it did so indirectly through injustice appraisal and group-based anger. Importantly, this finding converges with previous findings and theorizing about how social identity relates to collective action more generally (Grant, 2008; Mackie et al., 2000; Van Zomeren et al., 2008; Van Zomeren et al., 2004). Moreover, our findings suggest that merely identifying with Muslims does not lead directly to violent behaviour, which is consistent with the general observation that a relatively small minority of Muslims engage in violent actions to defend their fellow Muslims (Cordesman, 2017). Thus, our findings provide some evidence to refute the popular belief in the West that Islam as a religion is inherently violent and that there is a direct link between being Muslim and extremism (e.g., Murray, 2017; Wilders, 2012; see also Jolly, 2011).

Our findings that group-based anger directly predicted violent intentions across all four studies is worth noting since they provide further evidence for the role of anger in predicting nonnormative collective action despite other recent theorizing and findings that anger does not predict nonnormative collective action (e.g., Tausch et al., 2011). For instance, Tausch et al. found that contempt but not anger predicted nonnormative (violent) collective action. Although Tausch et al.'s general findings appear to be inconsistent with our findings, one of the exceptions to their findings was that anger was positively associated with support for violence by Islamist groups against Western military. This latter finding appears to be consistent with our present findings, and the observed inconsistencies between our findings and Tausch et al.'s are likely due to differences in the specific contexts in question. Consider that anger is an approach-related affect, such that it often promotes an effort to eliminate perceived violations of what "ought" to be, and often constitutes an act of rectifying an injustice (see Anjum et al., 2016; Anjum, Kidd, \& Aziz, 2018; Carver \& Harmon-Jones, 2009). With this in mind, anger is likely to be a more appropriate reaction in the context of perceived injustice of Western foreign policy and occupation, because these specific acts are more likely to evoke stronger emotional responses and "move against" tendencies compared to, for example, an increase in student 
tuition. Further research is required to clarify the role of anger in predicting nonnormative (violent) collective action in various contexts.

\section{Strengths, Limitations, and Future Research}

The present research provides a new contribution to the growing body of empirical research on Islamist extremism, since we demonstrate empirically that the social psychological underpinnings of Islamist extremism appear to be similar in Muslim-majority countries and the West. Psychological research, and social psychological theory in particular, has been based predominantly on samples from Western, educated, industrialized, rich, and democratic societies (WEIRD), and has therefore neglected to represent diverse human populations (Henrich, Heine, \& Norenzayan, 2010). Given that Muslim populations-particularly those living in Muslimmajority countries-represent hard-to-reach, non-WEIRD populations, a key strength of our research is our representation of this otherwise underrepresented population in social psychological research.

Naturally, there are also limitations of our research. First, one can argue that our measure of Muslim identification may lead the respondents to think of particular Muslim communities (i.e., Muslims in one's municipality or country), rather than a global Muslim community. Nevertheless, our logic follows a long line of social psychological research showing that the experience of group threat and discrimination leads to a common identity (see Klandermans, 2002). In order to unite the Muslim population around the globe into a unified community of ummah, Islamist groups depict Muslims, and Islam in general, to be under constant Western threat (see Wagemakers, 2008). Further, participation in collective action becomes a means to assert one's identity in the face of injustice and leads to protest against those perceived to be responsible (Drury \& Reicher, 2005). Thus, the connection between Muslim identification, perceptions of injustice, as well as anger and violent intentions directed toward the West are all natural from the perspective that "we" represent Muslims overall and "they" represent non-Muslim Westerners (meanwhile, a more specific Muslim identification would seem more appropriate for explaining regional intergroup dynamics, such as intolerance between Shia and Sunni communities). This reasoning is also consistent with research showing that Muslims in recent years have come to see themselves as a unified community which first identifies with other Muslims than with other categories (i.e., ethnicity, national identity; Roy, 2004; Saeed, Blain, \& Forbes, 1999).

Although there are theoretical reasons to believe that a global sense of identity-based on the perception of collective Muslim sufferingmay be an underlying factor in Islamist extremism, we did not actually measure identification with the global ummah. As such, the role of a global Muslim identity is somewhat speculative. Future research should attempt to improve upon our current studies by actually including items that specifically refer to the transnational element of Muslim identity.

Furthermore, two limitations of our research are our type of measures and our means of recruiting participants. Specifically, we assessed violent intentions with self-reports. As such, we cannot be certain that our model would also extend to actual extremist behaviour. On the other hand, intentions are generally good predictors of overt behaviour (see De Weerd \& Klandermans, 1999). Moreover, if social desirability (and similar motivations) influenced the present results, we would have expected to obtain different results in the Western sample. By extension, that would have made it harder to establish a common model across the different study contexts.

Our use of snowball sampling and Facebook sampling for Sample 1c and Study 2 are also less than optimal for recruiting participants. However, given that our research topic is a particularly sensitive issue in the contexts in which we sampled from, these sampling methods were the most feasible options. Future research should 
continue to sample from various hard-to-reach populations in order to assess how culturally diverse or universal the proposed key predictors of extremism are.

Finally, to directly compare the predictive utility of key variables across these groups, we refrained from using context-specific measures. Instead, we adopted an etic approach, which assumes that different processes (i.e., concepts, methods, measures) studied in one culture have significance in other cultures (Berry, 1989). This approach fits with our aim to examine whether the social psychological underpinnings of Islamist extremism in the West are similar to the underpinnings of Islamist extremism in countries with prolonged experience of Western military interventions. Nevertheless, an etic approach may overlook specific cultural perspectives or culturally specific behavioural nuances. Therefore, it would be relevant for future studies examining the social psychological underpinnings of Islamist extremism to adopt context-specific measures.

\section{Concluding Remarks}

Muslims around the world have come to see themselves as one unified group, and Western-led military interventions on Muslim-majority countries are likely to be perceived as an attack on the group as a whole. Such perceived attack may trigger feelings of injustice and anger, as well as violent action tendencies even in the absence of prolonged and ongoing experiences of Western military interventions. This research suggests that a combination of Muslim identity, perceived injustice, and group-based anger fuels violent intentions against Western targets. More importantly, this recipe for hostility seems equally applicable to Islamist extremism emerging in the West and in countries where people are living with the experience of Western military interventions.

\section{Funding}

The author(s) disclosed receipt of the following financial support for the research, authorship, and/or publication of this article: The research was supported by grants from the Sasakawa Young Leader's Fellowship to Milan Obaidi, and from the Marianne and Marcus Wallenberg Foundation to Robin Bergh. The research was also supported by Riksbankens Jubileumsfond (P15-0603:1).

\section{ORCID iDs}

Milan Obaidi (iD) https://orcid.org/0000-0001-6416 $-1805$

Gulnaz Anjum (iD https://orcid.org/0000-0002-2589 $-7884$

\section{Supplemental material}

Supplemental material for this article is available online.

\section{Notes}

1. In the current sample we also measured perceived group-based relative deprivation to answer a different research question. The data have not been reported before.

2. The data, indeed, confirmed this prediction. The mean of violent intentions for students from public universities was much higher than that for students from private universities.

3. Given the difficulty in reaching our samples, Sample $1 \mathrm{~b}$ was part of a larger battery of variables collected to answer different research questions within the same surveys. Variables not included here concerned, for example, a priming manipulation (manipulating perceived group threat), need for cognitive closure, and violent behavioural intentions and Muslim extremism. The variables for the current sample were measured before the experimental manipulation. The data have not been reported before.

4. This data set was previously reported in Obaidi et al. (2019) to answer a different research question.

5. Given the difficulty in reaching our samples, Study 2 was part of a larger battery of variables collected to answer different research questions within the same surveys. Variables not included here concerned, for example, the HEXACO Personality Inventory, openness to intellect, altruism, nonviolent behavioural intentions, violent behavioural intentions, support for violence, and group-based relative deprivation. The data have not been reported before.

6. Specifically, we measured violent behavioural intentions with two items, but only one of these referred particularly to violence in defence of Muslims. We acknowledge that the item in question does not identify a clear target. This item was directly translated from Doosje et al. (2013). To facilitate comparisons with other research in 
this area, we adopted most scales as they have been used in the past rather than introducing many modifications of this kind. However, both items have been validated in Obaidi, Bergh, et al. (2018), predicting violent intentions in defence of Muslims and/or Islam. More importantly, Obaidi et al. examined and addressed this issue in their paper by including two additional items that specifically targeted violent intentions on behalf of one's group (i.e., "I am ready to use violence to defend Islam" and "I am ready to use violence to defend other Muslims"), and they compared the results for the additional items with the two items used here. Their analyses showed a strong overlap between their added items and the current ones, and almost identical relations with the other variables we examine here (i.e., perceived injustice and anger).

\section{References}

Abrams, D., \& Grant, P. (2012). Testing the social identity relative deprivation (SIRD) model of social change: The political rise of Scottish nationalism. British Journal of Social Psychology, 51, 674689. http://doi.org/10.1111/j.2044-8309.2011. 02032.x

Adida, L. C., Laitin, D. D., \& Valfort, M. (2016). Wby Muslim integration fails in Christian heritage societies. Cambridge, MA: Harvard University Press.

Andre, V., \& Harris-Hogan, S. (2013). Mohamed Merah: From petty criminal to neojihadist. Politics, Religion \& Ideology, 14, 307-319. http:/ / doi.org/1080/21567689.2013.792655

Anjum, G., Aziz, M., \& Castano, E. (2019). The role of Fulbright Program in building positive perception and ally image of the U.S. among Pakistani scholars. Pakistan Journal of Psychological Research, 34, 123. http://doi.org/10.33824/PJPR.2019.34.1.1

Anjum, G., Castano, E., \& Aziz, M. (2016). Reparations to the victims of US drone strikes: Youth perspective from Pakistan. In S. S. Aneel, U. T. Haroon \& I. Niazi (Eds.), Securing peace and prosperity (pp. 245-249). Lahore, Pakistan: Sang-e-Meel.

Anjum, G., Kidd, D. C., \& Aziz, M. (2018). Hope in times of terrorism: Action-expressions speak louder than passive-sorrows. Journal of Behavioral Sciences, 28, 1-17. Retrieved from https://www. academia.edu/37915414/Hope_in_Times_of_ Terrorism_Action-Expressions_Speak_Louder_ than_Passive-Sorrows
Bansak, K., Hainmueller, J., \& Hangartner, D. (2016). How economic, humanitarian, and religious concerns shape European attitudes toward asylum seekers. Science, 354, 217-222. http://doi. org/10.1126/science.aag2147

Bauer, M., Cassar, A., Chytilová, J., \& Henrich, J. (2014). War's enduring effects on the development of egalitarian motivations and in-group biases. Psychological Science, 25, 47-57. http://doi. org/10.1177/0956797613493444

Becker, J. C., \& Tausch, N. (2015). A dynamic model of engagement in normative and non-normative collective action: Psychological antecedents, consequences, and barriers. European Review of Social Psychology, 26, 43-92. http://doi.org/10.1080/10 463283.2015.1094265

Berry, J. W. (1989). Imposed etics-emics-derived etics: The operationalization of a compelling idea. International Journal of Psychology, 24, 721-735. http:// doi.org/10.1080/00207598908247841

Bin Laden, O. (2002, November 24). Full text: Bin Laden's "letter to America." Retrieved from https:// www.theguardian.com/world/2002/nov/24/ theobserver

Branscombe, N., Schmitt, M., \& Harvey, R. (1999). Perceiving pervasive discrimination among African Americans: Implications for group identification and well-being. Journal of Personality and Social Psychology, 77, 135-149. http://doi. org/10.1037/0022-3514.77.1.135

Carver, C. S., \& Harmon-Jones, E. (2009). Anger is an approach-related affect: Evidence and implications. Psychological Bulletin, 135, 183-204. http:// doi.org/10.1037/a0013965

Chen, F. F. (2007). Sensitivity of goodness of fit indexes to lack of measurement invariance. Structural Equation Modeling, 14, 464-504. http://doi. org/10.1080/10705510701301834

Cheung, G. W., \& Rensvold, R. B. (2002). Evaluating goodness-of-fit indexes for testing measurement invariance. Structural Equation Modeling, 9, 233-255. http://doi.org/10.1207/S15328007SEM0902_5

Cordesman, A. H. (2017). Tracking the trends and numbers: Islam, terrorism, stability and conflict in the Middle East. Retrieved from Center for Strategic and International Studies website: https://www.csis.org/ analysis/tracking-trends-and-numbers-islam-terrorism-stability-and-conflict-middle-east

Cronin, A. K. (2013). Why drones fail: When tactics drive strategy. Foreign Affairs, 92, 44-54. Retrieved from https://www.jstor.org/stable/23526907 
Devereaux, R. (2015). Manhunting in the Hindu Kush. Retrieved from https://theintercept.com/dronepapers/manhunting-in-the-hindu-kush/

De Weerd, M., \& Klandermans, B. (1999). Group identification and political protest: Farmers' protests in the Netherlands. European Journal of Social Psychology, 29, 57-76. http://doi.org/10.1002/ (SICI)1099-0992(199912)29:8<1073::AIDEJSP986>3.0.CO;2-K

Doosje, B., Loseman, A., \& Van den Bos, K. (2013). Determinants of radicalization of Islamic youth in the Netherlands: Personal uncertainty, perceived injustice, and perceived group threat. Journal of Social Issues, 69, 586-604. https://doi. org/10.1111/josi.12030

Drury, J., \& Reicher, S. D. (2005). Explaining enduring empowerment: Acomparative study of collective action and psychological outcomes. European Journal of Social Psychology, 35, 35-38.

Ellemers, N., Wilke, H., \& Van Knippenberg, A. (1993). Effect of legitimacy of low group or individual status on individual and collective status-enhancement strategies. Journal of Personality and Social Psychology, 64, 766-778. http://doi. org/10.1037/0022-3514.64.5.766

Furnish, T. (2005). Beheading in the name of Islam. Middle East Quarterly, 2, 51-57. Retrieved from https://www.meforum.org/713/beheading-inthe-name-of-islam

Grant, P. R. (2008). The protest intentions of skilled immigrants with credentialing problems: A test of a model integrating relative deprivation theory with social identity theory. British Journal of Social Psychology, 47, 687-705. http://doi. org/10.1348/014466607X269829

Grant, P. R., Bennett, M., \& Abrams, D. (2017). Using the SIRDE model of social change to examine the vote of Scottish teenagers in the 2014 independence referendum. British Journal of Social Psychology, 56, 455-474. http://doi. org/10.1111/bjso.12186

Haynes, J. (2017). Donald Trump, "Judeo-Christian values," and the "clash of civilizations." The Review of Faith \& International Affairs, 15, 66-75. http://doi.org/10.1080/15570274.2017.1354463

Henrich, J., Bauer, M., Cassar, A., Chytilová, J., \& Purzycki, B. G. (2019). War increases religiosity. Nature Human Behaviour, 3, 129-135. http://doi. org/10.1038/s41562-018-0512-3

Henrich, J., Heine, S. J., \& Norenzayan, A. (2010). The weirdest people in the world? Behavioral and
Brian Sciences, 33, 61-83. http:/ /doi.org/10.1017/ S0140525X0999152X

Higher Education Commission Pakistan. (2017). Draft of the joint declaration of National Vice Chancellors' Conference on the role of universities in advancing national narrative to counter violence, extremism and terrorism. Retrieved from https://hec.gov.pk/english/services/universities/Pages/Joint-Declaration.aspx

Hogg, M. A., Meehan, C., \& Farquharson, J. (2010). The solace of radicalism: Self-uncertainty and group identification in the face of threat. Journal of Experimental Social Psychology, 46, 1061-1066. http://doi.org/10.1016/j.jesp.2010.05.005

Huntington, S. P. (1993). The clash of civilizations? Foreign Affairs. Retrieved from https:// www.foreignaffairs.com/articles/unitedstates/1993-06-01/clash-civilizations

Hussain, M. (2015). Former drone operators say they were "borrified" by cruelty of assassination program. Retrieved from https://theintercept.com/2015/11/19/ former-drone-operators-say-they-were-horrifiedby-cruelty-of-assassination-program/

Jolly, D. (2011, October 10). Dutch court acquits antiIslam politician. The New York Times. Retrieved from http://www.nytimes.com/2011/06/24/ world/europe/24dutch.html

Jöreskog, K. G. (1971). Simultaneous factor analysis in several populations. Psychometrika, 36, 409-426. https://doi.org/10.1007/BF02291366

Kelly, C., \& Breinlinger, S. (1996). The social psychology of collective action: Identity, injustice, and gender. London, UK: Taylor \& Francis.

Khan, M. S. (2005, September 1). London bomber: Text in full. Retrieved from http://news.bbc.co.uk/2/hi/ uk/4206800.stm

Khosrokhavar, F. (2005). Suicide bombers. London, UK: Pluto Press.

Klandermans, B. (2002). How group identification helps to overcome the dilemma of collective action. American Behavioral Scientist, 45, 887-900. http://doi.org/10.1177/0002764202045005009

Lankford, A. (2014). Public opinions of suicide bombers' mental health. Comprehensive Psychology, 3, 1-4. http://doi.org/10.2466\%2F07.CP.3.15

Loza, W. (2007). The psychology of extremism and terrorism: A Middle-Eastern perspective. Aggression and Violent Behavior, 12, 141-155. http://doi. org/10.1016/j.avb.2006.09.001

MacCallum, R. C., Browne, M. W., \& Cai, L. (2006). Testing differences between nested covariance structure models: Power analysis and null hypotheses. 
Psychological Methods, 11, 19-35. https://doi. org/10.1037/1082-989X.11.1.19

Mackie, D. M., Devos, T., \& Smith, E. R. (2000). Intergroup emotions: Explaining offensive action tendencies in an intergroup context. Journal of Personality and Social Psychology, 79, 602-616. http:// doi.org/10.1037//0022-3514.79.4.602

McKenzie, R. (2018). Anti-Muslim activities in the United States: Violence, threats, and discrimination at the local level. Retrieved from https://www.newamerica. org/in-depth/anti-muslim-activity/

Mummendey, A., Kessler, T., Klink, A., \& Mielke, R. (1999). Strategies to cope with negative social identity: Predictions by social identity theory and relative deprivation theory. Journal of Personality and Social Psychology, 76, 229-245. http://doi. org/10.1037/0022-3514.76.2.229

Murray, D. (2017). The strange death of Europe: Immigration, identity, Islam. London, UK: Bloomsbury Continuum.

Muthén, J. K., \& Muthén, B. O. (2012). Mplus user's guide (7th ed.). Los Angeles, CA: Author.

National Consortium for the Study of Terrorism and Responses to Terrorism (START). (2018). Global terrorism in 2017. Retrieved from https:// www.start.umd.edu/pubs/START_GTD_Overview2017_July2018.pdf

Nesser, P. (2006). Jihadism in Western Europe after the invasion of Iraq: Tracing motivational influences from the Iraq war on jihadist terrorism in Western Europe. Studies in Conflict \& Terrorism, 29, 323-342. http://doi.org/10.1080/10576100600641899

Obaidi, M., Bergh, R., Akrami, N., \& Anjum, G. (2019). Group-based relative deprivation explains endorsement of extremism among Western-born Muslims. Psychological Science, 30, 596-605. http:// doi.org/10.1177/0956797619834879

Obaidi, M., Bergh, R., Sidanius, J., \& Thomsen, L. (2018). The mistreatment of my people: Victimization by proxy and behavioral intentions to commit violence among Muslims in Denmark. Political Psychology, 39, 1-17. http://doi.org/10.1111/ pops. 12435

Obaidi, M., Kunst, J. R., Kteily, N., Thomsen, L., \& Sidanius, J. (2018). Living under threat: Mutual threat perception drives anti-Muslim and antiWestern hostility in the age of terrorism. European Journal of Social Psychology, 48, 567-584. http://doi. org/10.1002/ ejsp.2362

Obaidi, M., Thomsen, L., \& Bergh, R. (2018) "They think we are a threat to their culture": Meta-cul- tural threat fuels endorsement of extremist violence against the cultural outgroup. International Journal of Political Violence, 12, 1-13. http://doi. org/10.4119/UNIBI/ijcv.647

Pape, R. A. (2003). The strategic logic of suicide terrorism. American Political Science Review, 97, 342361. http://doi.org/10.1017/S000305540300 073X

Pargament, K. I., Smith, B. W., Koenig, G., \& Perez, L. (1998). Patterns of positive and negative religious coping with major life stressors. Journal for the Scientific Study of Religion, 37, 710-724. http:// doi.org/10.2307/1388152

Piven, J. S. (2002). On the psychosis (religion) of terrorists. In C. E. Stout (Ed.), The psychology of terrorism. Vol. 3: Theoretical understandings and perspectives (pp. 120-147). Westport, CT: Praeger.

Preacher, K. J., \& Coffman, D. L. (2006). Computing power and minimum sample size for RMSEA. Retrieved from http://quantpsy.org/

Roy, O. (2004). Globalised Islam: The search for a new ummah. New York, NY: Columbia University Press.

Ruffle, B., \& Sosis, R. (2007). Does it pay to pray? Costly ritual and cooperation. The BE Journal of Economic Analysis and Policy, 7, 1-35. http://doi. org/10.2202/1935-1682.1629

Saeed, A., Blain, N., \& Forbes, D. (1999). New ethnic and national questions in Scotland: Post-British identities among Glasgow Pakistani teenagers. Ethnic \& Racial Studies, 22, 821-844. http://doi. org/10.1080/014198799329279

Sageman, M. (2014). The stagnation in terrorism research. Terrorism and Political Violence, 26, 565680. http://doi.org/10.1080/09546553.2014.89 5649

Schmid, A. P. (2013). Radicalisation, de-radicalisation, counter-radicalisation-A conceptual discussion and literature review. Retrieved from International Center for Counter-Terrorism website: https://www. icct.nl/download/file/ICCT-Schmid-Radicalisation-De-Radicalisation-Counter-RadicalisationMarch-2013.pdf

Sidanius, J., Kteily, N., Levin, S., Pratto, F., \& Obaidi, M. (2016). Support for asymmetric violence among Arab populations: The clash of cultures, social identity, or counterdominance? Group Processes \& Intergroup Relations, 19, 343-359. http:// doi.org/10.1177/1368430215577224

Silber, M. D., \& Bhatt, A. (2007). Radicalization in the West: The homegrown threat. 
Silke, A. (2004). The road less travelled: Trends in terrorism research. In A. Silke (Ed.), Research on terrorism: Trends, achievements and failures (pp. 186-213). New York, NY: Routledge.

Simon, B., \& Klandermans, B. (2001). Politicized collective identity: A social psychological analysis. American Psychologist, 56, 319-331. http://doi. org/10.1037/0003-066X.56.4.319

Smith, H. J., \& Ortiz, D. J. (2002). Is it just me? The different consequences of personal and group relative deprivation. In I. Walker \& H. J. Smith (Eds.), Relative deprivation: Specification, development, and integration (pp. 91-115). Cambridge, UK: Cambridge University Press.

Stürmer, S., \& Simon, B. (2004). The role of collective identification in social movement participation: A panel study in the context of the German gay movement. Personality \& Social Psychology Bulletin, 30, 263-277. http://doi. org/10.1177/0146167203256690

Swedo, E. A., Sumner, S. A., Hillis, S. D., Aluzimbi, G., Apondi, R., Atuchukwu, V. O., . . . Masetti, G. M. (2019). Prevalence of violence victimization and perpetration among persons aged 13 24 years - Four sub-Saharan African countries, 2013-2015. Morbidity and Mortality Weekly Report, 68, 350-355. http://doi.org/10.15585/mmwr. mm6815a3

Tajfel, H., \& Turner, J. C. (1979). The social identity theory of intergroup conflict. In W. G. Austin \& S. Worchel (Eds.), The social psychology of intergroup relations (pp. 33-47). Monterey, CA: BrooksCole.

Tajfel, H., \& Turner, J. C. (2004). The social identity theory of intergroup behavior. In J. T. Jost \& J. Sidanius (Eds.), Key readings in social psychology: Political psychology (pp. 276-293). New York, NY: Psychology Press.

Tajuddin, A. (2018). Stateless and ethnic cleansing of the Rohingyas in Myanmar: Time for international intervention. Journal of Asia Pacific Studies, 4, 422-450. Retrieved from https://pdfs.semanticscholar.org/0b9b/8614068a127eb947208b951b2 721d21854dc.pdf

Tausch, N., Becker, J. C., Spears, R., Christ, O., Saab, R., \& Singh, P. (2011). Explaining radical group behavior: Developing emotion and efficacy routes to normative and non-normative collective action. Journal of Personality and Social Psychology, 101, 129-148. http://doi.org/10.1037/a0022728
Turner, J. C. (1999). Some current issues in research on social identity and self-categorization. In N. Ellemers, R. Spears \& B. Doosje (Eds.), Social identity: Context, commitment, content (pp. 6-34). Oxford, UK: Blackwell.

Turner, J. C., Hogg, M. A., Oakes, P. J., Reicher, S. D., \& Wetherell, M. S. (1987). Rediscovering the social group: A self-categorization theory. Oxford, England: Basil Blackwell.

Van Stekelenburg, J. (2013). Collective identity. In D. Snow, D. Della Porta, B. Klandermans \& D. McAdam (Eds.), The Wiley-Blackwell encyclopedia of social and political movements (pp. 219-225). Malden, MA: Wiley-Blackwell.

Van Zomeren, M., Postmes, T., \& Spears, R. (2008). Toward an integrative social identity model of collective action: A quantitative research synthesis of three socio-psychological perspectives. Psychological Bulletin, 134, 504-535. http://doi. org/10.1037/0033-2909.134.4.504

Van Zomeren, M., Spears, R., Fischer, A. H., \& Leach, C. W. (2004). Put your money where your mouth is! Explaining collective action tendencies through group-based anger and efficacy. Journal of Personality and Social Psychology, 87, 649-664. http://doi. org/10.1037/0022-3514.87.5.649

Voors, M. J., Nillesen, E. E. M., Verwimp, P., Bulte, E. H., Lensink, R., \& Van Soest, D. P. (2012). Violent conflict and behavior: A field experiment in Burundi. American Economic Review, 102, 941-964. http://doi.org/10.1257/aer.102.2.941

Wagemakers, J. (2008). Framing the "threat to Islam": Al-Wala' Wa Al-Bara' in Salafi discourse. Arab Studies Quarterly, 30,1-22. Retrieved from https:/ / www.jstor.org/stable/41858559

Walker, I., \& Smith, H. J. (2002). Relative deprivation: Specification, development, and integration. Cambridge, UK: Cambridge University Press.

Watson Institute for International and Public Affairs - Brown University. (2015). Afghan civilians. Retrieved from http://watson.brown.edu/costsofwar/costs/human/civilians/afghan

Wilders, G. (2012). Marked for death: Islam's war against the West and me. Washington, DC: Regnery.

Wright, S., Taylor, D. M., \& Moghaddam, F. M. (1990). The relationship of perceptions and emotions to behavior in the face of collective inequality. Social Justice Research, 4, 229-250. http://doi. org/10.1007/BF01048399 